\title{
Mediation: A Change in Finnish Court Culture?
}

\author{
Kirsikka Linnanmäki
}

\begin{abstract}
The topic of this chapter is court-connected mediation and how mediation has affected the court culture in civil cases in Finland. The focus is on the three following dimensions of the mediation system: on legislative, theoretical, and practical changes. The main normative change was the act that came into force in 2006. The new legislation led gradually to changes in practice as well. A significant amount of cases in the District Courts go to mediation today. The law defines judges also as mediators, and in practice many judges are trained and experienced mediators. Also, the theoretical framework for courts has expanded, since mediation theories constitute a relevant basis for the mediation process. The change in culture is also multidirectional. Not only has mediation moved into the legalistic court culture, but also the legal context affects mediation. Mediation has changed court culture by providing an alternative to court trial and it has brought new dimensions to the definition, role and function of courts of law.
\end{abstract}

\section{Introduction}

Culture can be defined in various ways and can refer to a variety of things. It can be defined as a way of life of a particular group of people at a particular time. ${ }^{1}$ Culture is also a compass that provides the direction or glue that holds groups together. ${ }^{2}$ It can be said that people make culture. ${ }^{3}$ The concept of culture is a rather abstract social construction that is affected and cross-affected by many things. Likewise, the changes in court culture can be defined in various ways depending on context and perspective.

\footnotetext{
${ }^{1}$ Cambridge Dictionary https://dictionary.cambridge.org/dictionary/english/culture (last visited 17 th of June 2020).

${ }^{2}$ Tharp (2009), p. 2.

${ }^{3}$ Menkel-Meadow (1993), p. 6.

K. Linnanmäki $(\bowtie)$

University of Helsinki, Yliopistonkatu 3, 00014 Helsinki, Finland

e-mail: kirsikka.linnanmaki@helsinki.fi
} 
Court culture is also part of the larger legal culture. ${ }^{4}$ In addition, it reflects the general atmosphere in the society. Traditionally, courts have represented broad stability and predictability. Court culture can be attached to court cases, to the norms that guide procedures and resolutions, to court personnel and their education and to court customers. Also, the views of court culture depend on the various functions that are related to the courts. This chapter, which can be defined as sociolegal, describes and analyses whether and how mediation has changed court culture in Finland and will focus on the norms that regulate court proceedings, behaviour patterns or practices and traditions in courts. ${ }^{5}$

Court culture can be divided into different spaces of time. Kaijus Ervasti has outlined the Finnish court and justice culture over five periods: (1) early law of local community (until the sixteenth century), (2) pre-modern law (from the sixteenth century to the nineteenth century), (3) modern law (from the nineteenth century to 1950s), (4) the law of the welfare state (from the 1950s to 1990) and (5) post-modern law (from 1990 onwards). According to him, the distinctive features of the development of the Finnish law system at the beginning of the twenty-first century are: (1) the growth of regulation and the globalisation of sources of law, (2) the disintegration of jurisprudence to several disciplines, (3) the decrease in civil proceedings and the increase in alternative dispute resolution, and (4) the privatisation of justice. ${ }^{6}$ Here, the focus will be on the post-modern law, the increase of alternative dispute resolution (especially mediation $)^{7}$ and the privatisation of justice.

Mediation has definitions in various sources such as legislation, research, handbooks and brochures, as well as in practice. Mediation can be understood in many ways, and different goals and details can be highlighted. Practices are also diverse. Mediation can, for example, be defined narrowly, referring to the modern, professional mediation process, or broadly, referring to various processes aiming at amicable resolution. Mediation as a system can also be divided into three different elements: theoretical models, applications in context, and mediation in action. ${ }^{8}$ In this chapter, mediation refers only to court-connected mediation in civil cases, and thus out-of-court mediation and mediation in criminal and administrative cases are not included.

\footnotetext{
${ }^{4}$ Ervasti (2005), p. 352.

${ }^{5}$ Various elements of defining culture, see Schein (2010), pp. 14-18.

${ }^{6}$ Ervasti (2005), pp. 352-371.

${ }^{7}$ Regarding the history of mediation in Nordic countries, see Ervasti (2018), pp. 226-227.

${ }^{8}$ Ervasti and Nylund (2014), pp. 139, 148. Regarding the mediation system with various definitions and perspectives in Nordic countries, see also Ervasti (2018).
} 


\section{Normative Change}

\subsection{Legislative Changes}

Before 2006, modern, professional mediation was not an option in the Finnish courts in civil cases. A court trial was the only available option. The procedure of court trial is regulated in detail in the Code of Judicial Procedure (4/1734). Just to mention some of the main characteristics, the judge presides over the procedure, the advocates present the case, and evidence is presented. The process and the conversations are meant to be formal, and the resolutions are to be motivated. The process and the outcome are open for complaint. The legal evaluation of the case (i.e., the judgement) is based on what is considered to be the legal truth according to legislation and requires due motivation.

During the trial, the parties can also come to an agreement. The courts have a general duty to support amicable resolutions (i.e., settlement) in dispositive cases. The actual proceeding for or method of promoting agreements is not regulated in detail, and there seems to be no clear theoretical background for the process itself. The promotion of settlement takes place in the framework of court trial and the norms of fair trial. ${ }^{9}$ The court can also confirm the agreement between the parties instead of giving a judgement in the case (the Code of Judicial Procedure, Chap. 5, Sect. 26 and Chap. 20).

Following the examples from Denmark and Norway, in 2006 the Finnish general courts (administrative courts are thus excluded) were by law given the option to provide court-connected mediation as an alternative process to a court trial in dispositive cases, however including child custody and contact cases ${ }^{10}$ (which also include indispositive elements). ${ }^{11}$ Court-connected mediation is regulated in the Act on Mediation in Civil Matters and Confirmation of Settlements in General Courts (394/2011, the Mediation Act, the law was reformed in 2011 due to the implementation of the EU-directive 2008/52/EY, but the original sections about mediation remained mainly untouched). Mediation is thus regulated in a separate law, apart from the Code of Judicial Procedure, to underline its alternative nature to court trial. In addition to mediation in the district courts, mediation is by law also available in the appellate court instances.

The Mediation Act regulates the mediation process on a very general level. It is left for the mediators and the parties to decide the process in more detail on a case by case basis. Some main principles, such as the aim of amicable resolution, free will and consent of the parties, as well as the neutrality and objectivity of the mediator, are regulated. The Act also requires that the mediator be a judge; thus, no one outside the court can act as the mediator in court-connected mediation. However,

\footnotetext{
${ }^{9}$ See, Ervasti (2004).

${ }^{10}$ Regarding the background and aims of the regulation, see Government bill HE 114/2004 vp.

${ }^{11}$ See, e.g., Aaltonen (2009), p. 132 and the referenced literature, Tolonen and Linnanmäki 2020, p. $310-313$.
} 
the mediator can have assistance in the process, either procedural or substantial, from an expert (Sect. 5). The Act does not define the experts as mediators, since the role of the mediator in court includes among other things the power to confirm the reached agreement. $^{12}$

The phases or techniques of mediation are not regulated in detail. The preparatory works, however, propose four phases and highlight the mediator's communication skills. ${ }^{13}$ In principle, no evidence or legal evaluation is required. Child custody and contact cases, however, constitute an exception in the legislation. Specifically, the Mediation Act requires that the child's best interests shall be taken into consideration in mediation (Sect. 10). The specific methods for this, however, are not regulated, and the evaluation of the child's best interests is left up to the individual mediator. The preparatory works, however, require that the legislation regarding child custody and contact shall be taken into consideration in mediation as well. ${ }^{14}$ During the past decade, more interest has been paid to how mediation can support the best interests of the child. This interest has been inspired by the Norwegian child-friendly models (using, e.g., psychologist expertise (sakkyndige) in various roles and combining mediation with court trial) on one hand and the English and Australian models (systemic and child-focused) on the other hand. ${ }^{15}$

Court-connected mediation involves many changes for court personnel, advocates as well as court customers. First, according to the law, judges are also mediators, when they are addressed to and serving on a mediation case (Act on Mediation Act, Sect. 5). Today, judges are not only experts of law and legal questions but also are responsible for the mediation process. Second, according to law, mediation aims to achieve amicable resolution and promote mutual understanding between the parties (Sects. 3 and 7). Court customers, the parties of the cases, are given different kind of responsibility and self-determination in mediation compared to in the court trial. They need to discuss their own case together with the other party. Thus, the parties, instead of their advocates, act the main roles in their process and create their own private justice. For the parties, mediation is also less risky, since they are the ones deciding the outcome and as the parties are, according to law, responsible for their own costs only (Sect. 27). ${ }^{16}$ Third, advocates are also expected to understand and adopt different roles, even though the law does not separately regulate their special role in mediation. They however need to know the differing legislation and other norms and practices between mediation and court trial, as well as to advise their clients to choose the best alternative for their case. ${ }^{17}$

The confirmation of an agreement can follow either court trial or mediation. The confirmation requires request and consent from both parties. According to law, the settlement may not be confirmed if it is contrary to law or clearly unreasonable or if

\footnotetext{
${ }^{12}$ Government bill HE 114/2004, various pages.

${ }^{13}$ Government bill HE 114/2004.

${ }^{14}$ Government bill HE 114/2004, pp. 48-49.

${ }^{15}$ See, Ministry of Justice (2013), pp. 47, 53, 70.

${ }^{16}$ See also Government bill HE 114/2004, various pages.

${ }^{17}$ Ministry of Justice (2016), p. 84-104.
} 
it violates the right of a third party. It is further regulated that the decision of the court on the confirmation of the settlement in the case is subject to appeal in accordance with the provisions on appeal of a judgment (the Code of Judicial Procedure, Sect. 3 and 5, Chap. 20, Mediation Act, Sect. 8). However it can be noted that mediation and court trial can give very different premises to evaluate the possible obstacles to the confirmation.

Mediation has meant normative changes and additions in the court culture. At the same time, some questions regarding mediation remain unregulated or simply linked to the legalistic framework and to the Code of Judicial Procedure. One explanation for this is that mediation was retrospectively added to the already existing court system, and the whole of the system with its new element was not opened for comprehensive re-evaluation or re-design. ${ }^{18}$ As a result, there remains some incoherence and even confusion between the various proceedings. In legislation, the general procedural framework for court-connected mediation is a combination of the Mediation Act and the Code for Judicial Procedure. The framework can be seen as a combination of (a) the legalistic court context, which highlights the objective criteria for justice, and (b) mediation as a flexible alternative highlighting the parties' subjective experiences in creating justice. ${ }^{19}$

\subsection{Theoretical Changes}

Before 2006, mediation theories were not given much attention in courts or in procedural law. However, the 1993 change with regard to settlement promotion and the oral preparatory stage gave some attention to the conflict resolution theories. ${ }^{20} \mathrm{Medi}-$ ation took this development even further, since it is an alternative to court trial and in many ways a different process. The two alternatives are based on different theoretical backgrounds and are also differently regulated. ${ }^{21}$ Court trial is regulated by several hundred paragraphs in the Code of Judicial Procedure accompanied by a large amount of case law, whereas only very few general provisions regulate mediation and the amount of case law is very limited. Regarding mediation, the process is guided mostly by cross-scientific mediation theories and ethics. ${ }^{22}$ The mediation process has its typical phases, but it is also flexible for case-by-case adaptation. Mediation has

\footnotetext{
${ }^{18}$ Regarding system design, see Ury et al. (1993), Menkel-Meadow (2006), Ervasti and Nylund 2014, pp. 552-553.

${ }^{19}$ Regarding the different discourses, see Ervasti (2005), p. 369.

${ }^{20}$ Regarding the change of court trial, see Haavisto (2002), pp. 165-251, 260-262, 287, Ervasti (2004), p. 433, Ervo (2014), Ervo (2017), p. 679.

${ }^{21}$ Ervasti (2011), pp. 8-11, 25.

${ }^{22}$ Ervasti (2011), pp. 16-19, 79, Ervasti and Nylund (2014), pp. 41-42, 558.
} 
thus also changed (or expanded) the theoretical framework for court proceedings, which can also be seen as part of the normative change. ${ }^{23}$

The Finnish legislator has taken into account the existence of mediation theories. Court-connected mediation is, in its preparatory works, linked to facilitative and evaluativemediation models. ${ }^{24}$ This applies to child custody and contact cases as well. However, the child's best interests shall also be taken into account. From the wide selection of mediation theories that exist today, the theoretical background for the Finnish mediation legislation is of course selective. ${ }^{25}$ However, during the below-

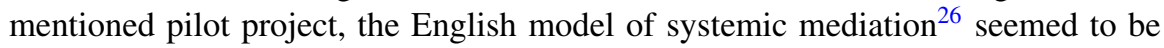
also one source of inspiration. ${ }^{27}$ On one hand, the Finnish co-mediation creates its own special application and practices. On the other hand, many links and similarities to international discussions can be noted. ${ }^{28}$

The mediation theories, as understood here, are based on cross-scientific research and other literature focusing especially on the mediation process, phases and techniques, as well as mediation principles and ethics. They constitute an important framework for mediation training, practices and research. ${ }^{29}$ The role of mediation theories in mediation practices can be compared to the role of legal theories in legal practises. Legal theories play an important role in defining the perspectives from which legal sources are viewed and individual cases are handled and resolved. Legal theories support lawyers into reflecting and justifying their practices. ${ }^{30}$ It is evident that mediation has gained ground in today's courts. This is due to legislation and the high case numbers, as described below. Thus, the importance of mediation theories has also become part of court culture. Mediation theories are part of mediation training provided to judges, as described below. Today, knowledge of mediation is also included in legal studies. ${ }^{31}$ Since 2006, court-connected mediation has also interested researchers of procedural law. ${ }^{32}$ Mediation has thus expanded the norms, values, behavioural patterns and traditions of the Finnish courts.

According to the general theoretical perspective adopted in Finland (in legislation, in the preparatory works, in research and in mediation training), ${ }^{33}$ the mediator is

\footnotetext{
${ }^{23}$ Regarding division of norms into rules and principles, see, e.g., Aarnio (1989), p. 78, Pajulammi (2014), p. 271.

${ }^{24}$ Government bill HE114/2004, pp. 4, 22. The concepts of facilitative and evaluative mediation were introduced by Riskin (1996).

${ }^{25}$ See also Nylund (2014), pp. 325-326.

${ }^{26}$ Parkinson 2011.

${ }^{27}$ See Ministry of Justice (2013) and (2016).

${ }^{28}$ Government bill HE 186/2013, Aaltonen (2015).

${ }^{29}$ For a description of conflict and mediation theories, see Ervasti and Nylund (2014), pp. 41-42.

${ }^{30}$ Syrjänen (2012), p. 339.

${ }^{31}$ According to University of Helsinki's website, the course of general procedural law includes alternative conflict resolution and inter alia knowledge of the Mediation Act (https://courses.hel sinki.fi/fi/200250/125443008).

${ }^{32}$ E.g., Knuts (2006), Ervasti (2011).

${ }^{33}$ See, e.g., Government bill HE 114/2004, Knuts (2006), various pages, Ervasti (2011), pp. 8-19, 47-52, Ministry of Justice (2013), pp. 22-24 and (2016), pp. 104-115, Ervasti (2018), p. 231.
} 
a facilitator of discussions between the parties and does not provide resolutions or even opinions to the parties. This lack of ruling authority is very different from the traditional role of a judge. The mediator is an expert in the mediation process and in promoting communication, but not necessarily in the content of the case (as in arbitration or court trial). The parties' self-determination to define their own interests and to negotiate their own agreements is the cornerstone of mediation. Mediation provides an opportunity for creative, tailor-made resolutions that can meet the parties' needs and are not only limited to the provisions of law. This differs from the judge's traditional role as well. The mediation process is informal and flexible and is based on trust and the neutrality and objectivity of the mediator. As a process, mediation is based on special techniques (e.g., questioning and active listening) and different phases that diverge from the ones in court trial and are not regulated by law.

In today's society, mediation, especially in the court context, however occurs in the shadow of the law. ${ }^{34}$ The legal and social frames cannot be ignored for the process and the resolution to be generally recognised and accepted. The mediation process and the reached agreement should therefore not infringe upon the parties' or a third party's legal rights. In addition, a case is suitable for court-connected mediation only if a legally defined dispute exists; other conflicts are thus excluded. ${ }^{35}$

Child custody and contact disputes in particular illuminate the collision between the legalistic and alternative perspectives. One example is the child's role in the process. In Finland, children are not legal parties to these disputes (Act on Child Custody and Contact Right, Sect. 14). ${ }^{36}$ The role of children in mediation is likewise deduced from the law that regulates child custody and contact issues and that is procedurally focused on court trials. ${ }^{37}$ It can be noted that the legalistic approach is dominant in this respect. An alternative approach could emphasise the perspectives of family systems and conflict resolution. It could recognise the importance of children's voices in family systems and communications when resolving family conflicts. The alternative perspective could give reason to view the child's role differently from the legalistic perspective. Mediation can be more informal, constructive and even healing compared to a court trial. Thus, it can meet the child's legal rights differently as well. For example, the need to protect children from the process could be different in the different processes. ${ }^{38}$

\footnotetext{
${ }^{34}$ The term is originally from Mnookin and Kornhauser (1979).

${ }^{35}$ Government bill HE 114/2004, p. 29.

${ }^{36}$ Government bill HE 224/1982, p. 6 .

${ }^{37}$ This is confirmed by the Finnish Legal Affairs Committee Statement 4/2005.

${ }^{38}$ Linnanmäki (2019), pp. 185-186.
} 


\section{Changes in Practice}

\subsection{Mediation Has Become a Popular Alternative in District Courts}

Before 2006, mediation was not an available alternative in the Finnish courts, and disputed cases were handled only in court trials. However, the court practices changed after the 1993 reform, becoming more informal and actively controlled and highlighting the parties' contributions to establishing their case and their expanding initiatives in particular, as well as attempts to reach a settlement instead of giving a verdict. ${ }^{39}$ Nonetheless, the practices by which settlements are promoted within the trial context are various, changing between facilitating communication, evaluating the case and using pressure. ${ }^{40}$

Court-connected mediation started to emerge in practice quite slowly during the first years. Initially, mediation was not very popular, despite many investments in mediation training inspired by Nordic and English and North American models and trainers. ${ }^{41}$ A new phase started in 2011, when a specific specialist-assisted application of court-connected mediation was piloted in child custody and contact disputes in selected courts, accompanied by a large-scale training and promotions for professionals and in general media. In the pilot project, four district courts offered comediation in child custody and contact disputes, where an expert-a social worker or psychologist - assisted the judge mediator. ${ }^{42}$ In 2014, this model was made nationwide and permanent in legislation. ${ }^{43}$ During the pilot project in 2011-2014, a significant rise in mediation case numbers in courts occurred. Simultaneously, there was a development and research project underway regarding facilitative mediation in family social services. ${ }^{44}$ There was thus a strong interest in developing family mediation services in Finland in the 2010s.

\footnotetext{
${ }^{39}$ Haavisto (2002), pp. 289-290.

${ }^{40}$ Ervasti (2004), various pages.

${ }^{41}$ See Ervasti (2011), p. 50 and Fig. 1 below.

${ }^{42}$ Ministry of Justice (2013 and 2016).

${ }^{43}$ Government bill HE 186/2013.

${ }^{44}$ Haavisto et al. (2014).
} 


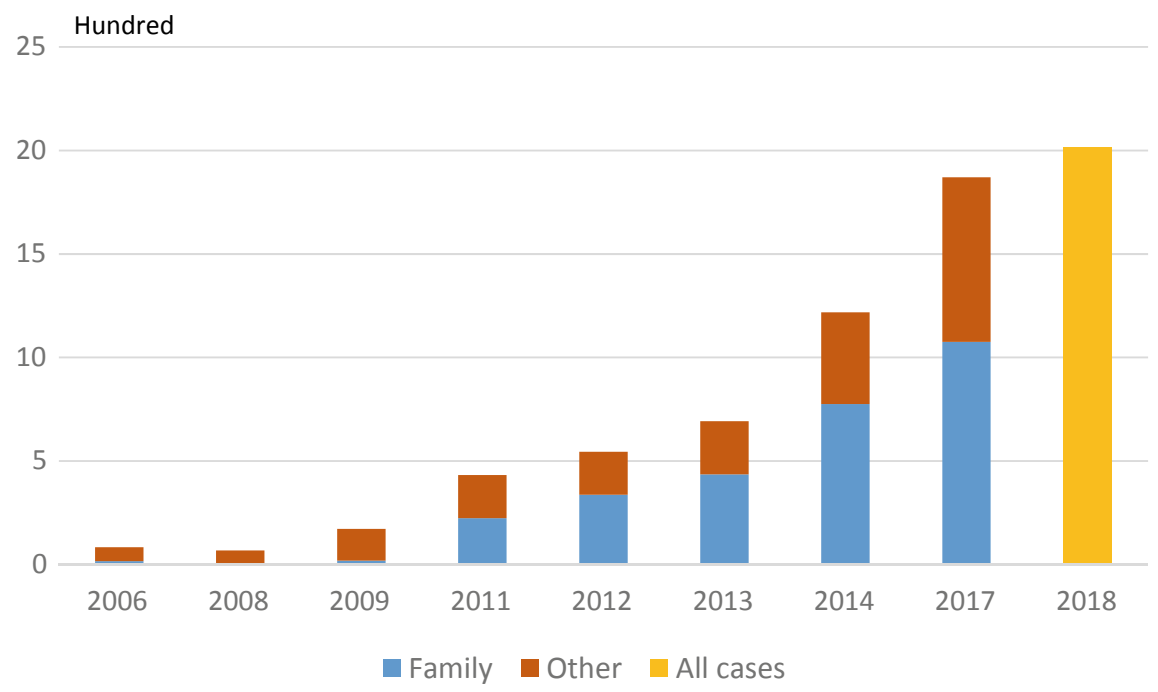

Fig. 1 Mediation in Finnish district courts in civil cases (family and other) 2006-2018 (Salminen and Ervasti (2014), p. 603, Linnanmäki (2019), p. 2.)

The mediation statistics regarding the district courts show that the mediation case numbers have risen significantly in the past ten years. ${ }^{45}$ More than half of the mediation cases are now family conflicts, and the rest are other civil conflicts such as neighbour- or work-related matters. Thus, court-connected mediation has now become an established practice in the district courts in Finland. However, there is some local variation among district courts ${ }^{46}$ with some being more active than others in promoting mediation, investing in mediation training for mediators and other lawyers and even promoting mediation in the media. ${ }^{47}$ In 2011, there was a great rise in mediation case numbers, mainly because of the above-mentioned pilot project. In 2018, more than 2000 cases in district courts went to mediation. This number represents a significant share of the approximately 8000 disputed civil cases (in the court case system, they are called 'broad claims') in the district courts. Mediation is especially popular in child custody and contact disputes. In general, the number of cases in the courts has not changed much but the popularity of mediation has clearly increased. ${ }^{48}$

Mediation is experienced to be different from a court trial in practice as well. Mediation has changed and expanded the behaviour and practices in many of the Finnish district courts. The roles of the parties, the mediators and the legal advisers of the parties in mediation are, in practice, different from the roles in court trial.

\footnotetext{
${ }^{45}$ Salminen and Ervasti (2014), p. 603, Linnanmäki (2019), p. 2.

${ }^{46}$ Salminen and Ervasti (2014), pp. 604-606.

${ }^{47}$ Savela (2017).

${ }^{48}$ See Ministry of Justice (2018), Ervasti (2018), p. 236.
} 
In mediation, the parties are acting in the main roles, and the legal advisers are not presenting or pleading the case on behalf of the parties. The mediator has no decision-making power but, rather, serves to promote the parties' communication and mutual ground for fruitful discussion. The mediation conversation is informal, and the process is flexible; however, it typically follows a certain structure and techniques to identify the parties' deeper interests and needs. The opening phase of the mediation session is important in order to give the parties a clear picture of the characteristics of mediation. The agreements can be tailor-made and include elements beyond legal elements, such as behavioural elements. ${ }^{49}$

Even though mediation training is not a prerequisite in legislation, in practice most of the mediating judges have taken a special training provided by the Finnish Ministry of Justice (since January 2020, National Courts Administration). Before 2006, no mediation training was provided for judges. Now, basic mediation training and special training focusing on child custody and contact cases is provided regularly. The training is complementary and consists of mediation theory and practical exercises. In practice, mediation training has been found to be important for amending the various professional roles of judges and advocates. ${ }^{50}$

Settlements as such, however, are not new in the district courts in Finland. As Kaijus Ervasti points out, 'Nordic conflict resolution culture and court culture has been very pragmatic in promoting settlement and avoiding full-scale trial. ${ }^{51}$ Even before the court-connected mediation was launched, approximately one third of the broad, disputed claims were resolved by settlement in courts. The promotion of settlements is not regulated in detail and, as mentioned above, is practised in various ways. ${ }^{52}$ In practice, the 1993 change in legislation was followed by a clear change towards more amicable, communication-based and future-oriented processes. ${ }^{53}$ The number of settlements has thus not changed much over the years, since even today about one third of these cases are resolved by settlement in either court trial or mediation. ${ }^{54}$ What has partly changed is the process by which the settlement is achieved. $^{55}$

\footnotetext{
${ }^{49}$ Regarding the changes in practice, see Ministry of Justice (2016), various pages, Linnanmäki (2019), pp. 240-294.

${ }^{50}$ Regarding mediation training for judges in practice, see Ervasti (2011), pp. 47-52, Ministry of Justice (2013), pp. 22-24 and (2016), pp. 104-115, Linnanmäki (2019), p. 238. According to my own experience, some district courts have also developed their own training and support for mediators.

${ }^{51}$ Ervasti (2018), p. 227.

${ }^{52}$ Ervasti (2004), various pages.

${ }^{53}$ Haavisto (2002), pp. 289-290, Salminen and Ervasti (2015), pp. 606-612. See also Ervo (2017), p. 679.

${ }^{54}$ Ministry of Justice (2018), p. 35.

${ }^{55}$ An interesting detail regarding court culture change is that in the court statistics provided by the Ministry of Justice in 2018, the absence of the word mediation (sovittelu), even though courtconnected mediation is an established practice in the district courts.
} 


\subsection{Interrelation Between the Elements of the Mediation System}

Mediation has entered district courts in significant numbers and brought a new alternative to court legislation and practices. However, a more detailed examination of mediation cases reveals that the mediation practises are diverse. Especially in childrelated cases, the practices have partly developed apart from the legislation and the original theoretical background for court-connected mediation. Moreover, the differences between theoretical background, legislation and mediation practices are not unique to Finland; research in other Nordic countries has had similar findings. ${ }^{56}$ The combination of legal and alternative perspectives is a challenge for courts and mediating judges and can lead to imbalance of the various elements of the mediation system, including theoretical models (developed in mediation research and other literature), applications in context (e.g., in court and regulated by legislation) and mediation practices in action. ${ }^{57}$

According to law and the preparatory works, mediation should follow the general, mainly facilitative and interest-based approach ${ }^{58}$ on which the basic mediation training in Finland is based. ${ }^{59}$ However, in practice, the child custody and contact cases are balancing between the facilitative and evaluative mediation model. ${ }^{60}$ This is due to the promotion of the best interests of the child within the mediation framework. The legislator has painted the mainly facilitative framework for mediation and left it for the mediators and experts to define how to promote the best interests of the child in practice. Thus, the roles of the mediator and the expert are mostly defined in practice. The practices and the training programme have developed different emphases regarding these roles.

The role of the expert has some evaluative elements. One element of her/his role is to provide, for example, general information regarding children's development. The mediator, on the other hand, leads and facilitates the conversations and, if necessary in order to settle the case, can also take a directive role. The mediator can also be a legal expert in the case, who can provide neutral, general legal information to the parties. ${ }^{61}$ It can be noted that the mediator and the expert both have significant power to guide the interpretation of the best interests of the child. ${ }^{62}$ The mediation practices have also had rather evaluative and directive as well as settlement-oriented

\footnotetext{
${ }^{56}$ See, e.g., Mykland (2011), pp. 160-186, Adrian (2012) various pages, Ervasti (2018), pp. 240-241 and the referenced research.

${ }^{57}$ Ervasti and Nylund (2014), p. 139, Ervasti (2018), p. 229.

${ }^{58}$ Government bill HE 114/2004, p. 22. See also Ervasti (2018).

${ }^{59}$ Ministry of Justice (2016), p. 105, Ervasti (2011), pp. 47-52, 79.

${ }^{60}$ Aaltonen (2015), p. 44, Linnanmäki (2019), p. 297.

${ }^{61}$ Aaltonen (2015), p. 110-118, Ministry of Justice (2013), pp. 45-60.

${ }^{62}$ Linnanmäki (2019), pp. 263, 279.
} 
elements. ${ }^{63}$ According to mediators, the pure facilitative techniques are not always sufficient when promoting the best interests of the child in mediation. ${ }^{64}$

Thus, in practice, mediation is a combination of facilitative and evaluative approaches. The practices have developed partly apart from the legal and theoretical framework behind the process. One reason for this could be the lack of special provisions regarding the mediation framework for the child-related cases. Another reason may be that the facilitative techniques and the broad perspective on conflict resolution are not always fully implemented in order to reach a settlement effectively under the institutional pressure. The gaps between theory, legislation and practices, however, can raise some questions regarding the procedural safeguards. ${ }^{65}$

One example regards the parties' self-determination-one of the cornerstones in mediation. As mentioned above, according to the law, the confirmation of agreement requires the request and consent of both parties, which can be seen as an expression of self-determination. In a previous study, ${ }^{66}$ however, absence of an explicit request or consent to confirm the agreement appeared. When reflecting on the mediation theories, however, one can ask whether it should be the parties who have the final word and will in how the mediation ends and what is the content of the agreement.

The legislation regulates case screening only on a very general level. According to Sect. 3 in the Mediation Act, the case shall be suitable for mediation, which means mainly that the parties can dispose the case. Mediation shall also be meaningful regarding the parties' claims. In child-related cases, the best interests of the child shall also be taken into account (Sect. 10). However, as already noted, the best interests of the child is open to various interpretations. In practice, the standards and timing for case screening vary. For example, family violence or substance abuse as such are not, by law, absolute hindrances for mediation in Finland; rather, they impose special requirements to adjust the mediation process and the evaluation of the best interests of the child. ${ }^{67}$

As mentioned above, the Norwegian model inspired the Finnish co-mediation model. However, the Norwegian model has faced criticism, since various proceedings and roles (mediator, evaluator, psychologist and judge) are mixed, which causes confusion and risk with regard to the procedural safeguards. ${ }^{68}$ For example, some

\footnotetext{
${ }^{63}$ Linnanmäki (2019), regarding the difference between amicability and contractuality and their roles in the legal system, see Koulu (2014), pp. 171-172.

${ }^{64}$ Aaltonen (2015), pp. $44-45$.

${ }^{65}$ About the process safeguards in mediation, see Ervasti and Nylund (2014).

${ }^{66}$ Linnanmäki (2019), especially pp. 289-290. The research included observations of six mediation sessions in various Finnish District Courts and 26 interviews with mediators and experts, advocates and parties during 2015-2016. The data were rather low in representativeness but gave a broad picture of each of the cases. No children were interviewed. This is because they did not participate in the mediation sessions and were not heard, which has been a common practice in Finland (regarding this practice, see Ministry of Justice (2013), pp. 74-75 and (2016), pp. 72-73).

${ }^{67}$ Ministry of Justice (2013), pp. 95-191, Ministry of Justice (2016), pp. 34-35, 90, Aaltonen (2015), pp. 181-202.

${ }^{68}$ Nylund (2018), p. 19, Bernt (2018), p. 130. See also Mykland (2011), p. 176.
} 
parties have experienced pressure to settle their case and directions for the settlement. ${ }^{69}$ In this respect, the Finnish solution, where the mediation is a separate proceeding from court trial, has some benefits, since the mediator has no authority to decide the case. However, in Finland, too, the roles of the judge and the mediator as well as the expert can also be mixed. The mediator has the final say in whether the agreement can be confirmed ${ }^{70}$; the role is in this respect judicial and evaluative. In practice, it has been noted, that the mediators may have been more directive and evaluative than the law suggests, in an effort to reach the best interests of the child. Mediation in child custody and contact disputes especially balances between facilitative and evaluative mediation models and between alternative and legal discourses. ${ }^{71}$

\subsection{Mediation and the Appellate Courts}

As mentioned above, court-connected mediation is, by law, also available in the appellate court instances (Mediation Act, Sect. 1), meaning the Courts of Appeal (hovioikeus) and the Supreme Court (Korkein oikeus). ${ }^{72}$ However, there has thus far not been exact information available regarding how much mediation is or not used in these instances in practice. As illustrated in the descriptions below, the Courts of Appeal have had at least some individual mediations. Concerning the Supreme Court, its role is to use the highest jurisdiction to supervise legal practices by its own resolutions, as well as to give preliminary rulings (Supreme Court Act, 665/2005). The (alternative) conflict resolution role has not been highlighted as one of the Supreme Court's functions. ${ }^{73}$ However, some individual cases in the higher courts have concerned the appropriateness of the mediation process and the confirmed settlement in district courts or in the courts of appeal. In these cases, the interaction between the legal and alternative perspectives is very interesting. Some examples will be described and analysed in more detail below.

In one case in the Helsinki Court of Appeal, ${ }^{74}$ one of the parties in the case claimed that there had been no prerequisites for mediation in the district court, that there was a failure in the mediation process and that the confirmed agreement was invalid since the other party had manipulated her during the mediation. She claimed that the agreement about child maintenance did not meet her wishes or the best interests of the child in question. The Court of Appeal found that there were prerequisites

\footnotetext{
${ }^{69}$ Koch (2008), Bernt (2018), various pages.

${ }^{70}$ This role of the mediator is not explicitly regulated in the Mediation Act, but it is stated in the Government bill HE 114/2004, p. 33.

${ }^{71}$ See Linnanmäki (2019), p. 318, Aaltonen (2015), p. 44.

${ }^{72}$ Expert assistance (co-mediation) in child-related disputes is, according to legislation, provided to district courts only (Act on Child Custody and Contact Right, Chap. 3a).

${ }^{73}$ See even the Supreme Court's website (www.korkeinoikeus.fi/en).

${ }^{74}$ HelHO 717/2019.
} 
for mediation, that no failure in the process existed and that there was no reason to change the agreement or return the case to the district court, since the claimant had failed to prove her perspective and claims. Her claims and views, however, during or after the mediation session, played no significant role in this decision. The District Court judge - who served as the mediator — was asked to give a statement about the mediation session, and her views were taken into account in the decision.

Regarding the court culture changes, it can be noted that the evaluation of the case in the Court of Appeal was strongly based on a legalistic perspective, legal issues and evidence, even though it was about mediation, an alternative to legal decisionmaking based on parties' self-determination and free will and a non-decisive role of the mediator. It is also interesting that, even though mediation should never diminish the parties' right to legal proceedings, and even though the claimant wanted the case to be handled in a court trial, the confirmed agreement was not nullified or returned to the district court for new proceedings. In addition, the mediator was heard even though there is a prohibition in the law against the mediator witnessing in the court about the mediation session without the consent of the parties. This issue was not problematised in the court decision. It also seems, that the mediation process itself and its theoretical background did not get attention in the decision.

Mediation should promote the free will and mutual understanding of the parties. This is the core of mediation as an alternative. If one or both of the parties feel the processes and agreements have been pushed, directed or manipulated, the process and the agreement cannot meet this goal of mediation. However, it is understandable that court decisions, such as confirmation of an agreement, cannot be nullified or returned to new proceedings merely because one party starts to regret the outcome if no signs of resistance were apparent in the mediation session. Nullification or returning of a case to a new proceeding on this basis would obviously be contrary to the legal certainty of the court decision. It is also of importance that the other party of the case can count of the certainty of the decision. Agreements as such are also highly legal by nature. ${ }^{75}$ However, the balance between the legalistic and alternative perspectives is challenging. There are neither specific requirements nor guidelines in legislation to evaluate mediation as an alternative process.

In 2018, the first case about court-connected mediation was handled in the Supreme Court of Finland. ${ }^{76}$ The court considered whether the Court of Appeal should have confirmed the agreement in the case after a mediation session. The question also concerned the duration of the mediation session. The mediator had confirmed the agreement only after (not at the end of) the mediation session, based on an e-mail conversation between the parties and the mediator. One of the parties declared in her e-mail that she did not want the agreement to be confirmed. Despite this, the Court of Appeal confirmed the agreement anyway. The Supreme Court found that the Court of Appeal had acted wrongly in confirming the agreement, repealed the resolution and returned the case to the Court of Appeal.

\footnotetext{
${ }^{75}$ See Hietanen-Kunwald (2018), various pages.

${ }^{76}$ KKO 2018:55.
} 
It can be noted that in this case the Supreme Court paid attention to the special characteristics of mediation. It stated that the process is an alternative to court trial and thus regulated separately but that the confirmation of the agreement is a legal decision made by the court. According to the Supreme Court, the agreement is confirmed by the same rules that regulate the confirmation of an agreement during the court trial. Moreover, a complaint about the agreement is to be made by the same rules; in other words, there are no exceptions concerning mediation. While the Supreme Court did not expressly point this out, it seems that the mediation process itself is thus not open for complaint by the parties. This is the case despite the fact that there is a fine line between the process and the agreement with regard to infringements of access to justice. However, what is highlighted in the judgment is that mediation is based on the free will and consent of the parties. If the parties wish to end the mediation, they can do so at any time and are not required to justify this choice. The confirmation of the agreement requires consent and request from both parties.

In this Supreme Court case as well, the mediator (i.e., the judge who confirmed the agreement) was asked to give a statement about the mediation session and the steps prior to confirming the agreement. The prohibition to witness about mediation was not seen as an obstacle. Thus, the interpretation of the legal norms seems to be that the prohibition to witness applies only to the resolution of the substantive parts of the case or other cases handled in court.

In 2020 the Supreme Court gave another decision regarding mediation (KKO 2020:75). In this case the Supreme Court reversed a final decision of a district court. It stated that the settlement confirmed in a court-connected mediation manifestly based on misapplication of the law, since a public purchase witness (kaupanvahvistaja) did not witness the purchase of a real property, which is an absolute requirement in the law for a valid purchase and for the buyer to be granted title to the property. This Supreme Court decision clearly shows that, even though creative outcomes as such are possible and one asset in mediation as an alternative process, certain absolute formal requirements need to be followed in mediation too when confirming agreements, in order for the parties to implement their legal rights. It can however be noted, that the Supreme Court did not state much about mediation itself and how the requirements regarding the confirmation of the agreement reflect the mediation process.

\section{The Many Faces of Change}

Mediation has opened the paradigm of courts and procedural law towards more alternatives in legislation, in practice, and in theory. The districts courts in Finland today are multidoor courthouses ${ }^{77}$ providing both court trial and mediation. ${ }^{78}$ Judges not only interpret legislation and case facts but also promote settlements and creative

\footnotetext{
${ }^{77}$ Regarding this concept, see Sander (1964).

${ }^{78}$ This is aligned also in Government bill HE 114/2004, p. 4.
} 
conflict resolution in mediation. Also, the law recognises judges as mediators. In practice, many district court judges in Finland today are also specialised and trained mediators.

The basis for Finnish court-connected mediation is in parties' self-determination and freedom of agreement. ${ }^{79}$ The law does not separate various types of conflicts; thus, in principle, all cases are considered equally. The only particular exception stated in the Mediation Act concerning the substance of the case is that of cases involving children (Sect. 10). This is understandable, since child custody and contact disputes constitute a significant share of the disputed cases in courts. Another reason for this may be that children's matters have been important in the Finnish welfare state. According to law, the child's best interests need to be taken into account when mediating child-related cases. The child's best interest is not defined in detail. However, in confirming the agreement, the legislation regarding child custody and contact is expected to be taken into account. ${ }^{80}$ The mediation process in child custody and contact cases is not regulated in any more detail. The child's best interest is thus open to various interpretations. ${ }^{81}$

Mediation in the court context is affected by the legal context. Mediation in court is a hybrid ${ }^{82}$ balancing between the legalistic and the alternative traditions, occurring in the shadow of the law. However the law and its shadows ${ }^{83}$ have changed as well. The law is more pluralistic and fragmented, than before and it is no longer always clear what is the law and what is the shadow. ${ }^{84}$ This is due to both internationalisation and privatisation. The emphasis of human rights affects the interpretations of law and makes law in some respect more flexible and reflexive. Thus, the previously criticised legalisation of mediation ${ }^{85}$ is today inevitable. The legalisation also differs from the traditional perspective due to the fragmentation and reflexivity of the legal context. ${ }^{86}$

Law could regulate certain questions regarding mediation in more detail. For example, at the moment there is no regulation on mediation training. The guarantee for due mediation process is however dependent on the individual mediators. Also some special characteristcs regarding mediation could be regulated separately rather than by referring to the regulation designed for court trials. In this way mediation theories would not need to compete for attention with the legal interpretations. The traditional role of the courts is to apply law, and law in their activities binds the judges.

\footnotetext{
${ }^{79}$ Government bill HE 114/2004, pp. 5, 52.

${ }^{80}$ Since December 2019, however, there has been an amendment to the law that the child's views shall be taken into account if possible in mediation too.

${ }^{81}$ Linnanmäki (2019), various pages. See also Salminen (2018).

${ }^{82}$ The term 'hybrid' has been used in various ways, in referring to processes mixing alternative and legal elements (such as evaluation and mediation or arbitration and mediation), as well as mixing different mediation models (such as facilitative and evaluative). See Lindell (2000), p. 26, Knuts (2006), p. 55, Kovach and Love (1998), Bernt (2011), p. 67, Lowry (2004), p. 115, Ervasti and Nylund (2014), pp. 73, 167.

${ }^{83}$ The expression is originally presented by Mnookin and Kornhauser (1979).

${ }^{84}$ Linnanmäki (2019), p. 306.

${ }^{85}$ See Ervasti and Nylund (2014), pp. 188, 555.

${ }^{86}$ See Linnanmäki (2019), various pages.
} 
But what about mediation and the mediator? One can thus ask, whether there is need to regulate the roles of mediator and judge more separately in order to promote the alternative nature of the mediation process in courts.

By adding regulation-legislation or soft law-the mediation paradigm is of course moving away from its unregulated origins and total freedom of the parties. ${ }^{87}$ It can also stiffen the flexible nature of mediation. New directions in the life span of mediation are however taken in accordance with today's society. This can lead towards more appropriate alternatives, more training, evolution of processes, new skills and standards, and to new system designs.

\section{Conclusion}

Court-connected mediation has affected the court culture in Finland with regard to civil cases. This change has occurred on normative, practical, and theoretical levels. Mediation has changed the culture by bringing an alternative that is more informal, client-centred and conflict resolution-oriented. However, it has also made the court culture and the courts' role more diverse. Court-connected mediation is not just mediation, since the legalistic perspective dominates the courts' functions as well as the interrelation between court trial and mediation. The judges are balancing between different roles of legal resolution providers as well as facilitators and evaluators.

In 2006, the law introduced court-connected mediation in Finland. The purpose of doing so was to add alternatives in courts and to promote agreements between the parties. Simultaneously legislation defined judges in mediation as mediators. In practice, many judges today are also trained and experienced mediators. The mediation alternative has also expanded the theoretical dimension of court culture, since mediation theories play a significant role as the framework for mediation.

Since 2006, the amount of mediation cases has risen significantly in the district courts. In 2018, more than 2000 cases in court went to mediation. Mediation is especially popular in child custody and contact disputes. The number of cases in mediation represents a large share of the disputed civil claims (about 8,000 per year) in the district courts. Measured in case numbers, mediation thus has an established role as an alternative process to court trial in Finnish District Courts and has changed the court culture significantly. Before the mediation alternative was introduced, about one third of all broad claims in the district courts were settled, and the number has not changed radically over the years. However, the process by which settlement is reached has partly changed. Mediation can promote more durable and tailor-made settlements, even though the realisation of this objective in mediation practices in Finland has not yet been comprehensively researched. ${ }^{88}$ The material differences and similarities between mediated agreements and court decisions is an interesting topic for future research as well.

\footnotetext{
${ }^{87}$ Regarding the history of mediation, see, e.g., Ervasti and Nylund (2014), pp. 51-61, 138.

${ }^{88}$ In Denmark and Norway, see Adrian and Mykland (2014).
} 
In legislation, and according to experiences from practice, mediation has many differences compared to a court trial. The court context, however, creates a special framework for mediation. In the court context as it is regulated today, it is a challenge to fit together the three elements of mediation-theoretical models, applications in legislation, and mediation in action. ${ }^{89}$ The requirements placed by legislation and the institutional framework are natural characteristic for courts. However, a multidoor courthouse also needs multiple theoretical and legislative frames. Also, the cases in the appellate courts emphasise that there can exist complications of bringing together the legalistic and alternative discourses.

The change in court culture and court paradigm due to mediation is also multidirectional. Not only has mediation affected the courts, but the legal context has also shed its light on mediation. Mediation has become partly regulated and drawn into a legal context. ${ }^{90}$ Mediation is a private and alternative process on the one hand but is also part of the social and legal context on the other hand. This balancing between various functions and roles is evident in the Finnish courts of law today, and it also shapes the court culture.

\section{References}

Aaltonen AK (2009) Lapsioikeus ja lapsen oikeus tuomioistuimissa. Edita, Helsinki

Aaltonen AK (2015) Huoltoriitojen sovittelu tuomioistuimessa. Kauppakamari, Helsinki

Aarnio A (1989) Laintulkinnan teoria: yleisen oikeustieteen oppikirja. WSOY, Juva

Adrian L (2012) Mellem retssag og rundbordssamtale: retsmægling i teori og praksis. Jurist- og Økonomforbundets Forlag, København

Adrian L, Mykland S (2014) Creativity in court-connected mediation: myth or reality? Negot J 4:421-439

Bernt C (2011) Meklerrollen ved mekling i domstolene. Fagbokforlaget, Bergen

Bernt C (2018) Custody mediation in Norwegian courts: a conglomeration of roles and processes. In: Nylund A et al (eds) Nordic Mediation Research. Springer, Cham, pp 105-132

Ervasti K (2004) Käräjäoikeuksien sovintomenettely: empiirinen tutkimus sovinnon edistämisestä riitaprosessissa. Oikeuspoliittinen tutkimuslaitos, Helsinki

Ervasti K (2005) Tuomioistuinkulttuurin kehityslinjoja. Oikeus 4:352-375

Ervasti K (2011) Tuomioistuinsovittelu Suomessa. Oikeuspoliittinen tutkimuslaitos, Helsinki

Ervasti K (2018) Past, present and future of mediation in Nordic countries. In: Nylund A et al (eds) Nordic Mediation Research. Springer, Cham, pp 225-245

Ervasti K, Nylund A (2014) Konfliktinratkaisu ja sovittelu. Edita, Helsinki

Ervo L (2014) Nordic court culture in progress: historical and futuristic perspectives. In: Ervo L, Nylund A (eds) The future of civil litigation. Access to courts and court-annexed mediation in the Nordic countries. Springer, London, pp 383-407

Ervo L (2017) Välimiesmenettely vaihtoehtoisena riidanratkaisumenettelynä Suomessa ja Ruotsissa. Defensor Legis 4:661-679

\footnotetext{
${ }^{89}$ See Ervasti and Nylund (2014), p. 139, Ervasti (2018), p. 229.

${ }^{90}$ Regarding the convergence between court trial and mediation especially regarding mandatory mediation, see Macfarlane 2002, p. 308.
} 
Finnish Legal Affairs Committee Statement 4/2005 vp. Lakivaliokunnan mietintö. Hallituksen esitys riita-asioiden sovittelua ja sovinnon vahvistamista yleisissä tuomioistuimissa koskevaksi lainsäädännöksi

Government bill HE 224/1982 vp, Hallituksen esitys eduskunnalle laeiksi lapsen huollosta ja tapaamisoikeudesta ja holhouslain muuttamisesta sekä niihin liittyvien lakien muuttamisesta

Government Bill HE 114/2004 vp, Hallituksen esitys Eduskunnalle riita-asioiden sovittelua ja sovinnon vahvistamista yleisissä tuomioistuimissa koskevaksi lainsäädännöksi

Government Bill HE 186/2013 vp, Hallituksen esitys eduskunnalle laeiksi lapsen huollosta ja tapaamisoikeudesta annetun lain, riita-asioiden sovittelusta ja sovinnon vahvistamisesta yleisissä tuomioistuimissa annetun lain 5 ja 10 §:n sekä sosiaalihuoltolain 17 §:n muuttamisesta

Haavisto V (2002) Court work in transition: an activity-theoretical study of changing work practices in a Finnish district court. University of Helsinki, Helsinki

Haavisto V et al (2014) Perheasioiden sovittelun uudet tuulet: havaintoja, mallinnuksia ja arvioita FASPER-hankkeen pohjalta. Unigrafia, Helsinki

Hietanen-Kunwald P (2018) Mediation and the legal system. Extracting the legal principles of civil and commercial mediation. Unigrafia, Helsinki

Knuts G (2006) Förfarandegarantier vid domstolsanknuten medling. Suomalainen Lakimiesyhdistys, Helsinki

Koch K (2008) Evaluering av saksbehandlingsreglene for domstolene i barneloven: saker om foreldreansvar, fast bosted og samvær. Barne- og likestillingsdepartementet, Oslo

Koulu S (2014) Lapsen huolto- ja tapaamissopimukset: oikeuden rakenteet ja sopivat perheet. Lakimiesliiton kustannus, Helsinki

Kovach KK, Love LP (1998) Mapping mediation: the risks of Riskin's grid. Harvard Negot. L Rev. 3:71-110

Lindell B (2000) Alternativ tvistlösning. Iustus förlag, Uppsala

Linnanmäki K (2019) Lapsen etu huoltoriidan tuomioistuinsovittelussa: lapsioikeutta, sovitteluteoriaa ja empiriaa yhdistävä tutkimus. Alma Talent, Helsinki

Lowry RL (2004) Evaluative mediation. In: Folberg J et al (eds) Divorce and family mediation: models, techniques and applications. The Guilford Press, New York, pp 72-91

Macfarlane J (2002) Culture change: a tale of two cities and mandatory court-connected mediation. J Dispute Resolut 2:241-325

Menkel-Meadow C (2006) Exporting and Importing ADR: 'I've Looked at Life from Both Sides Now'. Dispute Resolut Mag 5-8

Ministry of Justice (2013) Report 25. Asiantuntija-avusteista huoltoriitojen sovittelua koskeva kokeilu käräjäoikeuksissa 1.1.2011-31.12.2013. Loppuraportti

Ministry of Justice (2016) Report 12. Ei niin suurta riitaa, ettei sopu sitä sovita

Ministry of Justice (2018) Court statistics

Mnookin RH, Kornhauser L (1979) In the shadow of the law: the case of divorce. The Yale L J 88:950-997

Mykland S (2011) En studie av mekleratferd i norske rettsmeklinger. NHH. Institutt for strategi og ledelse. PhD. thesis No 2011/02

Nylund A (2014) Access to justice: Is ADR a Help or Hindrance? In: Ervo L, Nylund A (eds) The future of civil litigation: access to courts and court-annexed mediation in the Nordic countries. Springer, London, pp 325-344

Nylund A (2018) A dispute systems design perspective on Norwegian child custody mediation. In: Nylund A et al (eds) Nordic Mediation Research. Springer, Cham, pp 9-26

Pajulammi H (2014) Lapsi, oikeus ja osallisuus. Talentum, Helsinki

Parkinson L (2011) Family mediation. Appropriate dispute resolution in a new family justice system. 2nd edn. Jordan Publishing Limited, Bristol

Riskin L (1996) Understanding mediators' orientations, strategies, and techniques: a grid for the perplexed. Harvard Negotiation Law Rev 1:7-51 
Salminen K (2018) Mediation and the best interests of the child from the child law perspective. In: Nylund A et al (eds) Nordic Mediation Research. Springer, Cham, pp 209-222

Salminen K, Ervasti K (2015) Tuomioistuinsovittelun yleistyminen ja tuomioistuimen tehtävät. Lakimies 5:591-612

Savela A (2017) Kohti sovinnollisempaa riidan ratkaisua: kokemuksia tuomioistuinsovittelun kehittämisestä Oulun käräjäoikeudessa. In: Riekkinen J (eds) Oikeutta oikeudenkäynnistä täytäntöönpanoon: Juhlajulkaisu Tuula Linna. Alma Talent, Helsinki, pp. 330-345

Schein EH (2010) Organizational culture and leadership, 4th edn. Jossey Bass, San Francisco

Syrjänen J (2012) Tuomarin harkinnan rajat: irti legalismin taakasta. Oikeustiede - Jurisprudentia XLV:335-391

Tharp BM (2009) Defining 'culture' and 'organisational culture': from anthropology to the office. Haworth, Philadelphia PA

Tolonen H, Linnanmäki K (2020) Uudistunut lapsenhuoltolaki. Alma Talent, Helsinki

Ury WL et al (1993) Getting disputes resolved: designing systems to cut the costs of conflict. Jossey-Bass, San Francisco

Open Access This chapter is licensed under the terms of the Creative Commons Attribution 4.0 International License (http://creativecommons.org/licenses/by/4.0/), which permits use, sharing, adaptation, distribution and reproduction in any medium or format, as long as you give appropriate credit to the original author(s) and the source, provide a link to the Creative Commons license and indicate if changes were made.

The images or other third party material in this chapter are included in the chapter's Creative Commons license, unless indicated otherwise in a credit line to the material. If material is not included in the chapter's Creative Commons license and your intended use is not permitted by statutory regulation or exceeds the permitted use, you will need to obtain permission directly from the copyright holder.

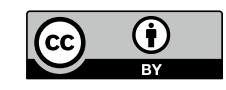

